\title{
A NOVEL BACKFILL MATERIAL FOR ROOF SUPPORTS IN THE CUT-THROUGH ENTRIES OF LONGWALL MINING
}

\author{
Jingyi Cheng, Wenfeng Li, Peng Zhang
}

Original scientific paper

To enhance underground mining safety, researchers developed high-water and fast-setting cement (HWFSC). HWFSC essentially consists of two components and can be mixed with large quantities of water. To determine its mechanical strength, a series of uniaxial compressive strength tests were conducted on HWFSC specimens with different water-to-solid ratios. Results indicate that peak strength declined significantly with the increase in W/S ratio, whereas residual strength increased gradually with this enhancement. The feasibility of backfilling cut-through entries with HWFSC is then evaluated through a case study. The LaModel program was used to assess the yielding of the fender pillar and the deformation of the cut-through entry. Results also show that the use of HWFSC to backfill the cut-through entry addressed complicated ground control problems effectively. Further analysis also suggested that HWFSC was the optimal backfill material in terms of both economic cost and roof support safety.

Keywords: backfill material; cut-through entry; field monitoring; high-water and fast-setting cement (HWFSC); numerical modelling; roof support

Novi materijal ispune za potpornje krovišta u prokopima kod širokočelnog otkopavanja

Izvorni znanstveni članak

U svrhu povećanja sigurnost u rudnicima, istraživači su razvili brzo skrutnjavajući cement koji sadrži veliku količinu vode (HWFSC). HWFSC se u biti sastoji od dvije komponente i može se miješati s velikim količinama vode. Kako bi se odredila njegova mehanička čvrstoća izvršen je niz ispitivanja jednoosne tlačne čvrstoće na HWFSC uzorcima s različitim omjerima vode i krute tvari. Rezultati su pokazali da je vršna čvrstoća znatno opadala s povećanjem W/S omjera, dok je zaostala čvrstoća pritom postupno rasla. Izvedivost ispune prokopa HWFSC-om tada se provjerila analizom slučaja. LaModel programom se procijenilo popuštanje bočnog stupa i deformacija prokopa. Rezultati također pokazuju da se primjena HWFSC za ispunu prokopa pokazala uspješnom u rješavanju složenih problema upravljanja s tla. Daljnja je analiza također pokazala da je HWFSC optimalni materijal za popunjavanje i zbog ekonomične cijene i sigurnosti krovišta.

Ključne riječi: materijal za popunjavanje; nadgledanje radova; numeričko modeliranje; potpora krovišta; prokop; skrutnjavajući cement s velikim količinama vode (HWFSC)

\section{Introduction}

In longwall mining, cut-through entries may need to be established near the middle of a panel and along the headgate side to the tailgate side because of ventilation requirements, safety concerns, and other mine-specific conditions. However, the main problem with these open entries is that the longwall must cut through them during retreat mining. This process generates front abutment loads and then induces ground control issues related to these entries $[1 \div 3]$.

The primary support for cut-through entries (and/or pre-driven recovery rooms) is normally similar to that for other development entries in the same mine. The secondary or supplementary supports that are installed to handle abutment pressure during longwall retreat mining can be divided into the following three types [4]:

1. The complete backfill of cut-through entries,

2. Supplemental roofs and/or rib bolt reinforcement without standing support, and

3. Rows of standing support with or without a supplemental roof and/or rib bolt reinforcement.

Intuitively, the second method is the most desirable. However, this technique is limited in that the roof layers of the entries must be composed of strong rock and must be free of either major fractures or geological defects $[5$, $6]$.

Meanwhile, loading behavior must be considered if the first and third methods are employed, as well as the cuttability of the backfill and/or standing support materials. Seymour et al. [7] and Chen et al. [8] concluded that the uniaxial compressive strength (UCS) values and deformation moduli of backfill materials should be approximately $2,07 \div 6,9 \mathrm{MPa}$ and $0,7 \mathrm{GPa}$, respectively. Various cases that apply supplemental standing support have been reported as well $[6,9 \div 11]$, thus indicating that this support is critical to maintaining the stability of cut-through entries. The first and third methods can generate high support densities and improve ground control. However, the values of all variables are equal. Furthermore, these methods are mainly limited by their high cost.

Therefore, this paper proposes an alternative material with which to backfill cut-through entries in longwall mining, thereby improving the safety of underground mining and lowering the economic cost of addressing the front abutment load induced by longwall retreat mining.

\section{Novel material: HWFSC}

Several different cementitious materials are used in pumpable roof support technology. The most common material is calcium sulfo-aluminate (CSA) cement, which generates a high yield and fast-setting grout through ettringite formation [12]. However, CSA-based grout is expensive. Thus, researchers have developed HWFSC as an alternative in an effort to reduce system cost.

\subsection{Description of the material}

HWFSC is composed of high bauxite cement with gypsum, lime, compounding retarder, retarding agents, and activators. These compounds facilitate the mixture of 
HWFSC with large quantities of water. For instance, the water-to-solid (W/S) ratio may vary from 2,0 to 3,0 in terms of weight. With respect to volume, more than $87 \%$ of the mixtures consist of water.

HWFSC has two major material components of equal weight (i.e., Parts $\mathrm{A}$ and $\mathrm{B}$ ), and it is pumped symmetrically. If a single part is mixed with water, then it acts as a slurry and does not transform into a gel within 24 h. Once two slurries are combined, however, they set and cure rapidly (in a few minutes), followed by a process of heat release that lasts approximately $30 \mathrm{~min}$.

\subsection{Performance characteristics}

HWFSC performance is characterized depending on the selected W/S ratio by weight. Tab. 1 shows the results of the UCS tests on the HWFSC specimens, which are conducted using a MTS servo-hydraulic testing system when the $\mathrm{W} / \mathrm{S}$ ratio ranges from 1,0 to 3,0 . The peak strength of the HWFSC specimens generally increases significantly with the decrease in $\mathrm{W} / \mathrm{S}$ ratio. However, the setting time of HWFSC decreases considerably as the $\mathrm{W} / \mathrm{S}$ ratio decreases when two slurries are mixed. Meanwhile, the peak strength of the HWFSC samples in the early stage $(2 \mathrm{~h})$ accounts for $53 \%$ of its final UCS when W/S ratio is low (for instance, 1,0). Despite a high ratio $(2,5$ or 3,0$)$, the strength of the HWFSC samples in the early stage $(2 \mathrm{~h})$ can still reach up to $38 \%$ of the final strength. Thus, the mixed HWFSC material can generate high loading support rapidly. This support helps address some ground control issues in longwall mining, such as tailgate roof support during longwall retreat mining.

The entries may experience severe deformation during longwall retreat mining; thus, the residual strength and length of time that can be sustained by the support must be evaluated. Fig. 1 depicts the complete stressstrain curves of the HWFSC specimens with W/S ratios that range from 1,0 to 3,0 . This figure indicates that: (1) the specimen with a W/S ratio of 1,0 is brittle; (2) residual strength is $1,86 \mathrm{MPa}$ when the specimen is prepared with a $\mathrm{W} / \mathrm{S}$ ratio of 1,5 ; and (3) the specimens display residual stresses of $4,0 \div 5,44 \mathrm{MPa}$ when the $\mathrm{W} / \mathrm{S}$ ratio ranges from 2,0 to 3,0 . Moreover, they are generally elasticperfect plastic materials.

Table 1 UCS tests on HWFSC specimens ${ }^{1)}$

\begin{tabular}{|c|c|c|c|c|c|}
\hline \multirow{2}{*}{$\begin{array}{c}\text { W/S } \\
\text { ratio }\end{array}$} & Setting time & \multicolumn{4}{|c|}{ Peak strength of UCS tests / MPa } \\
\cline { 3 - 6 } & mins & $2 \mathrm{hr}^{2}$ & $1 \mathrm{~d}^{2)}$ & $7 \mathrm{~d}^{2}$ & $28 \mathrm{~d}^{2)}$ \\
\hline 1,0 & 8 & 10,2 & 15,8 & 17,9 & 19,1 \\
\hline 1,5 & 10 & 4,5 & 9,1 & 10,4 & 11,5 \\
\hline 2,0 & 12 & 3,3 & 6,3 & 7,9 & 8,7 \\
\hline 2,5 & 14 & 2,7 & 4,7 & 6,2 & 7,1 \\
\hline 3,0 & 16 & 2,1 & 4,0 & 5,1 & 5,4 \\
\hline
\end{tabular}

${ }^{17}$ Specimens were prepared and tested in accordance with the standards of the American Standard for Testing and Materials (ASTM) and of the International Society for Rock Mechanics (ISRM), and

${ }^{2)}$ The specimens were prepared at a specified time after the two slurries were mixed.

All of the specimens presented in Fig. 1 were prepared and tested after curing for $7 \mathrm{~d}$.

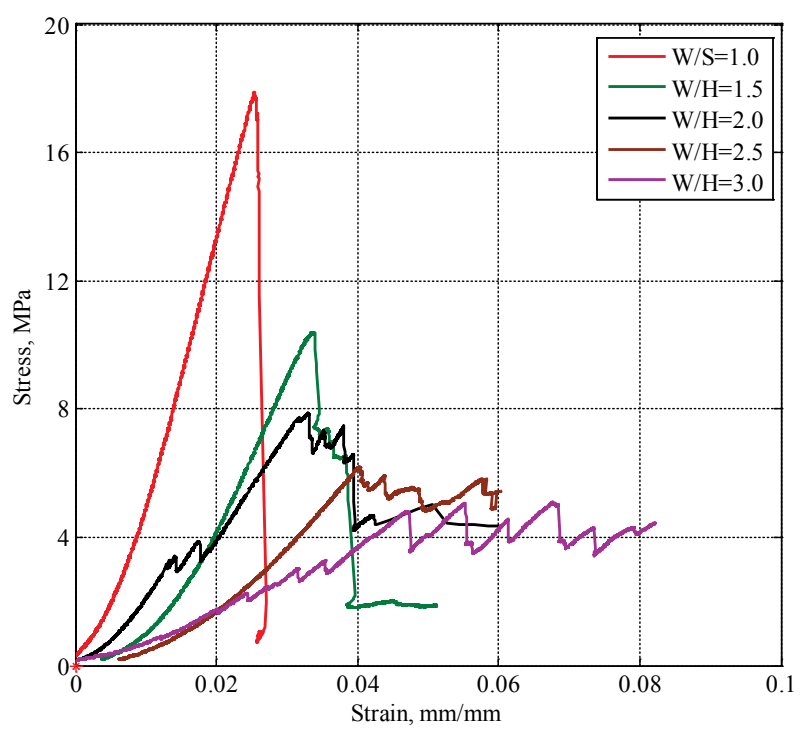

Figure 1 Stress-strain curves of the HWFSC specimens with W/S ratios ranging from 1,0 to 3,0

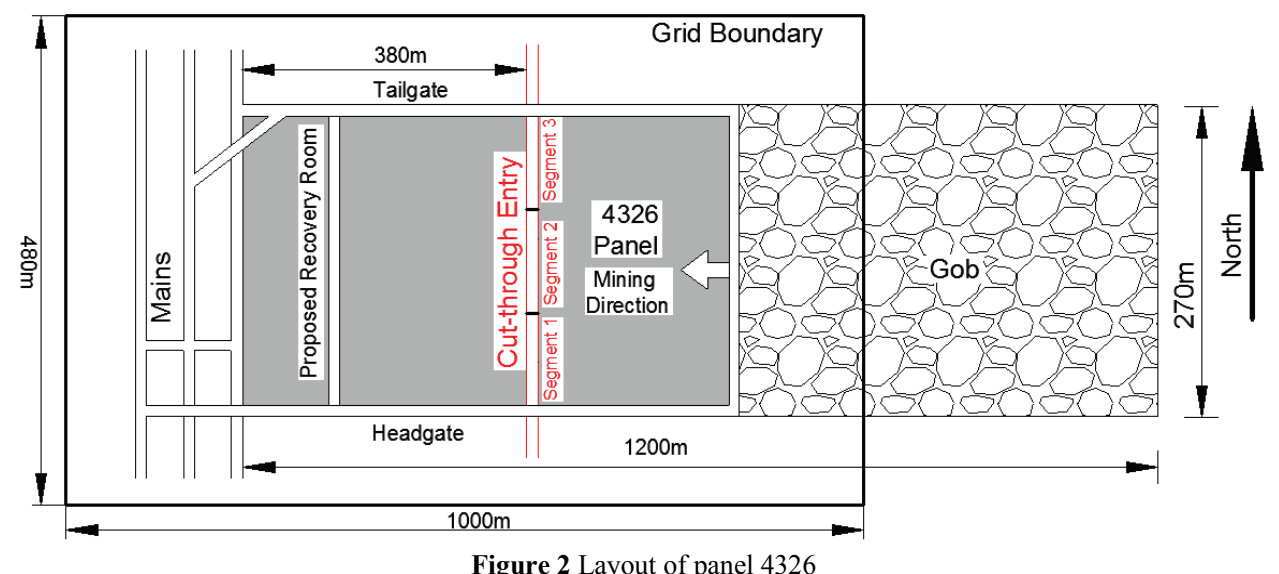

\section{Application of backfill \\ 3.1 Geological description}

Fig. 2 presents longwall panel 4326 in coal mine A, which is located in Shanxi Province, China. Panel 4326 is situated in the No. 3 coal seam, which is almost flat, is 3,5 $\mathrm{m}$ thick, and measures $1200 \times 240 \mathrm{~m}$. A geological survey suggests that this coal seam is uniform and has an average overburden depth of $232 \mathrm{~m}$. Given that the No. 3 coal seam is mildly gassy in accordance with regulations, a single-entry system was applied to the longwall panel. The cross-sections of all of the gateroads were 5,0 $\mathrm{m}$ wide 
$\times 3,5 \mathrm{~m}$ high with the exception of the cut-through entry, which was $4,0 \mathrm{~m}$ wide $\times 3,5 \mathrm{~m}$ high. The cut-through entry was developed for the drainage systems of other panels prior to the generation of panel 4326. Longwall retreat mining in panel 4325 induces high front abutment load; thus, the cut-through entry must be stabilized and well-designed.
According to the core logs of exploration in this area (Tab. 2), the rock layers above the coal seam consist of sandy shale and sandstone (in ascending order), whereas the floor layers below the coal seam consist of shale and sandy shale (in descending order).

Table 2 Rock layers and the properties of the rock mechanics in the No. 3 coal seam.

\begin{tabular}{|l|c|c|c|c|c|c|c|}
\hline \multicolumn{1}{|c|}{ Rock layer } & $\begin{array}{c}\text { Overburden } \\
\text { depth / } \mathrm{m}\end{array}$ & Thickness / m & $\begin{array}{c}\text { Young's } \\
\text { modulus / GPa }\end{array}$ & $\begin{array}{c}\text { Poisson's } \\
\text { ratio }\end{array}$ & $\begin{array}{c}\text { Uniaxial } \\
\text { compressive } \\
\text { strength / MPa }\end{array}$ & $\begin{array}{c}\text { Density } \\
\mathrm{g} / \mathrm{cm}^{3}\end{array}$ & $\begin{array}{c}\text { Internal } \\
\text { friction angle } \\
/ \text { degree }\end{array}$ \\
\hline Sandstone & 225,0 & 4,5 & 20,4 & 0,16 & 82,7 & 2,67 & 34 \\
\hline Sandy shale & 229,5 & 2,5 & 13,5 & 0,19 & 69 & 2,55 & 32 \\
\hline No. 3 coal seam & 232,0 & 3,5 & 3,1 & 0,35 & 18 & 1,36 & 27 \\
\hline Shale & 235,5 & 1,8 & 6,3 & 0,26 & 36,5 & 2,40 & 29 \\
\hline Sandy shale & 237,3 & 5,0 & 12,6 & 0,20 & 65,1 & 2,51 & 33 \\
\hline
\end{tabular}

\subsection{Roof support design}

To compare the safety levels provided by different roof support strategies for the cut-through entry, three types of entry reinforcement (Fig. 3) were proposed and applied to three segments of the cut-through entry (Fig. 2): (1) the strategy involving conventional wood cribs arranged in one row was adopted for segment 1; (2) the strategy involving conventional wood cribs arranged in two rows was applied to segment 3; and (3) the entry in segment 3 was backfilled with HWFSC.

Fig. 3 depicts the details of the roof support design for the three segments of the cut-through entry. Two separate rows of conventional wood cribs were set up as supplementary supports for segment 1, as shown in Fig. $3 \mathrm{a}$. The space between each row was $1,0 \mathrm{~mm}$. In segment 2, HWFSC supported the roof as backfill material (Fig. $3 b)$. In addition, a single row of conventional wood cribs was installed in segment 3, as depicted in Fig. 3c. These wood cribs were located in the vicinity of the rib of the fender pillar, measured $0,5 \mathrm{~m}$, and were constructed with poplar. Each layer of wood cribbing was composed of two crib blocks containing four contact points. These crib blocks were $0,15 \mathrm{~m}$ wide $\times 1,0 \mathrm{~m}$ long. The $\mathrm{W} / \mathrm{S}$ ratio of the HWFSC material was set to 2,5 for backfill application mainly given its strength and cost (Fig. 1).

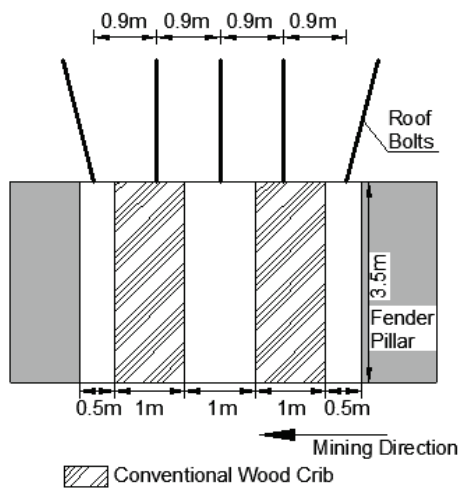

(a) For segment 1

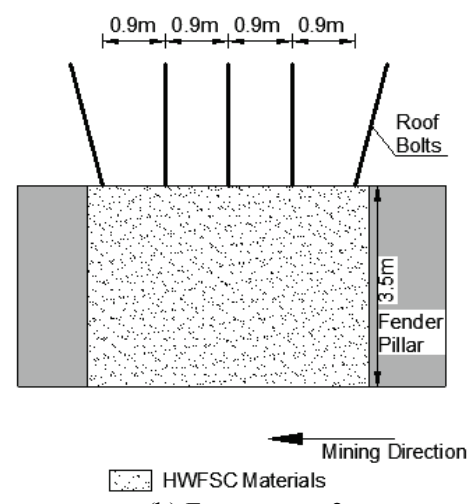

(b) For segment 2

Figure 3 Roof support for cut-through entry

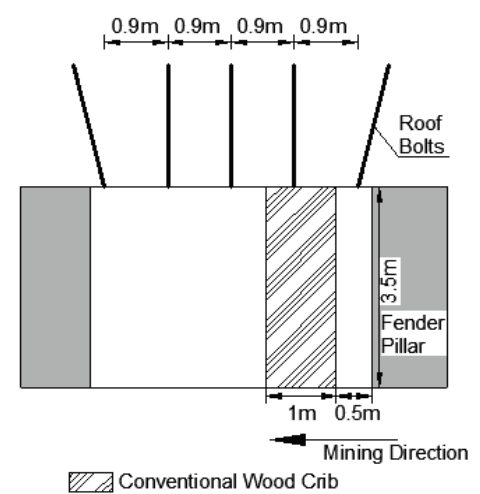

(c) For segment 3
Roof bolts were installed as primary supports during the development of the cut-through entry. These bolts were 2,0 $\mathrm{m}$ long. Moreover, the installation patterns measured $0,9 \mathrm{~m} \times 0,9 \mathrm{~m}$.

\subsection{Numerical evaluation of the proposed roof support design}

The boundary element model program LaModel was used to evaluate the yielding process of the fender pillar and the safety of the roof support design. Dr. Heasley originally wrote this program in 1994 [13], and literature has shown that it can be applied to structural mine planning and analysis [3, 14, 15]. However, the material behavior of coal, gob, overburden strata, wood cribs, and the HWFSC materials related to the current project had to be calibrated to obtain accurate model outputs.

The coal seam was discretized with $0,5 \mathrm{~m}$ square elements in a $2000 \times 960$ element grid with a model boundary for the LaModel simulation of this cut-through area, as displayed in Fig. 2. The rock mass was simulated with a modulus of $20,7 \mathrm{GPa}$ and $10,0 \mathrm{~m}$ thick laminations. The strain-softening material model was applied to investigate the coal seam, and element strengths were determined based on an in-situ coal strength of 6,2 $\mathrm{MPa}$ in conjunction with the Mark-Bieniawski formula for pillar strength. This formula was implemented into the coal material "wizard" in LaModel [16]. The elastic modulus of coal was set to 2,07 GPa. Moreover, the residual seam stress and strain values of the coal materials were approximated based on the study conducted by 
Karabin [17]. The gob was presumably a strain-hardening material, and its stress-strain relationship was determined using Salamon's gob model equation [18]. Symmetrical seam boundary conditions were implemented on the northern, southern, and eastern sides of the grid, whereas the western side was subject to a rigid boundary condition.

Given the same roof bolting design, these three segments (Fig. 3) mainly differ in terms of the standing supports for the cut-through entry. The first roof layer is composed of 2,5 $\mathrm{m}$ thick sandy shale (Tab. 1), and the roof bolt is only $2,0 \mathrm{~m}$ long. When the longwall face approaches the cut-through entry, front abutment load increases significantly and the roof bolts yield. Thus, the roof bolts have a weaker effect on the stabilities of the entry and of the fender pillar than the standing supports do. Given the front abutment load and the strength of the standing supports, the roof bolting effect can technically be ignored. Therefore, it was disregarded in the numerical simulation analysis conducted in this study.

In LaModel simulation, seven mining steps were considered: (1) the final development of panel 4326 is the first step, and (2) the other six steps are simulated when fender pillar widths are $20,10,7,5,3$, and $0 \mathrm{~m}$. Prior to the initiation of these seven steps, the inputted mechanical properties for the wood cribs and HWFSC materials had to be calibrated, including peak and residual strength.

\subsubsection{Wood cribs}

In 1999, Mucho and Barczak [19] rigorously tested the mechanical behavior of conventional wood cribs in the unique mine roof simulator developed by the National Institute of Occupational Safety and Health. Fig. 4 presents the load displacement curves of the various wood cribs, which were plotted according to the English unit.

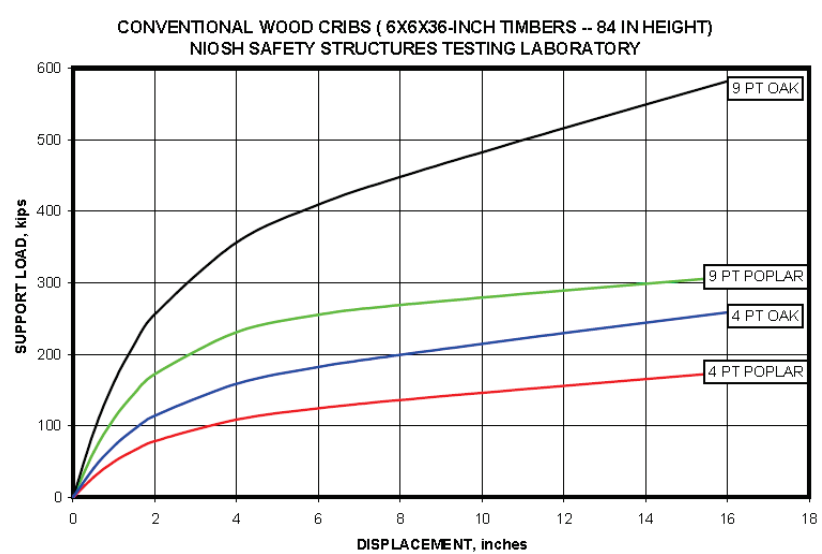

Figure 4 Load displacement curves for conventional wood cribs [19]

Table 3 Mechanical properties of the linear elastic-plastic wood cribs in LaModel

\begin{tabular}{|c|c|c|c|}
\hline Property & $\begin{array}{c}\text { Elastic modulus } \\
/ \mathrm{MPa}\end{array}$ & $\begin{array}{c}\text { Peak strength / } \\
\mathrm{MPa}\end{array}$ & $\begin{array}{c}\text { Plastic modulus } \\
/ \mathrm{MPa}\end{array}$ \\
\hline Value & 17,19 & 0,532 & 4,86 \\
\hline
\end{tabular}

The equivalent stress-strain curve of the "4 PT POPLAR" wood crib can be calculated and plotted based on the width and height of the wood cribs shown in Fig. 4 In LaModel simulation, the linear elastic-plastic material represents the wood cribs. Tab. 3 and Fig. 5 display the material properties and the corresponding stress-strain curve, respectively.

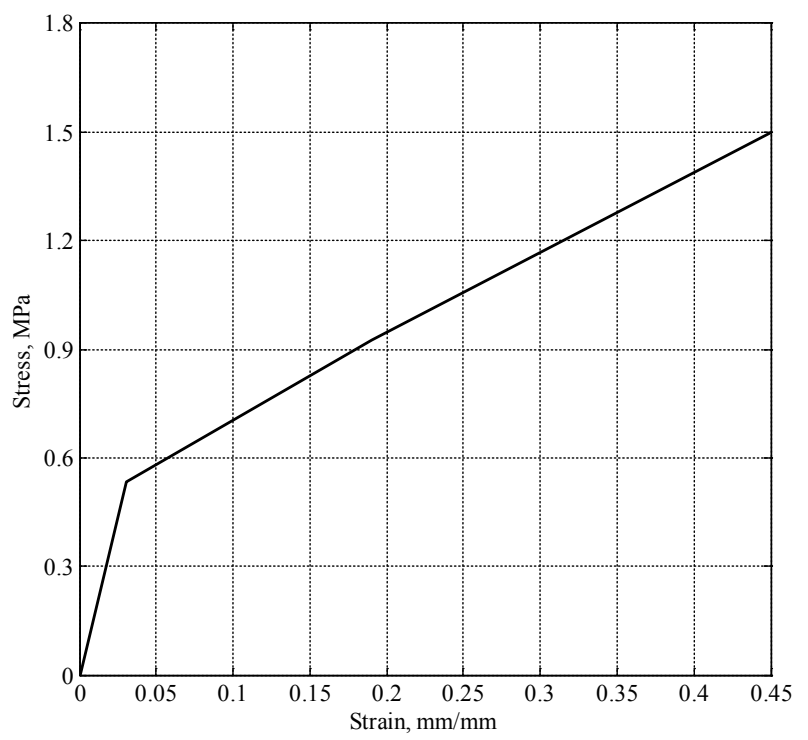

Figure 5 Stress-strain curve of the linear elastic-plastic material used to simulate wood cribs in LaModel

\subsubsection{HWFSC materials}

The backfill materials must be sufficiently strong; nonetheless, they must be easy to cut with a shearer. As mentioned previously, the $\mathrm{W} / \mathrm{S}$ ratio of the HWFSC material was set to 2,5 for backfill application. Thus, HWFSC was assumed to be a linear elastic-plastic material, as per the tested stress-strain curve in Fig. 1. Nonetheless, peak strength cannot be incorporated directly into numerical models without appropriate modification because the stress-strain curves displayed in Fig. 1 were derived from laboratory tests on small-scale specimens. Hoek and Brown [20] developed methods that relate these laboratory tests to the strength of large-scale rock masses. However, their methods may not be applicable in this case because of the homogeneous and isotropic features of the HWFSC material. Tan [21] introduced the following Eq. (1) to accurately calculate the peak strength of a cement structure that is subject to triaxial stress:

$$
f_{0}=f_{c}^{\prime}\left(-9,338+10,338 \sqrt{1+1,368 \frac{f_{r}}{f_{c}^{\prime}}}-2 \frac{f_{r}}{f_{c}^{\prime}}\right)
$$

Where $f_{0}$ is the peak strength in the triaxial stress state $(\mathrm{MPa}) ; f_{c}^{\prime}$ is $\mathrm{UCS}(\mathrm{MPa})$; and $f_{r}$ is the lateral confining pressure $(\mathrm{MPa})$.

The lateral confining pressure of the backfilled HWFSC material was presumably 1,2 times the in-situ vertical stress. Thus, the peak strength of the HWFSC in the field was calculated using Eq. (1) and displayed in Tab. 4. The corresponding stress-strain curve is plotted in Fig. 6.

Table 4 Mechanical properties of the linear elastic-plastic HWFSC materials in LaModel

\begin{tabular}{|c|c|c|c|}
\hline Property & $\begin{array}{c}\text { Elastic modulus } \\
/ \mathrm{MPa}\end{array}$ & $\begin{array}{c}\text { Peak strength / } \\
\mathrm{MPa}\end{array}$ & $\begin{array}{c}\text { Plastic modulus } \\
/ \mathrm{MPa}\end{array}$ \\
\hline Value & 152,75 & 31,33 & 0 \\
\hline
\end{tabular}




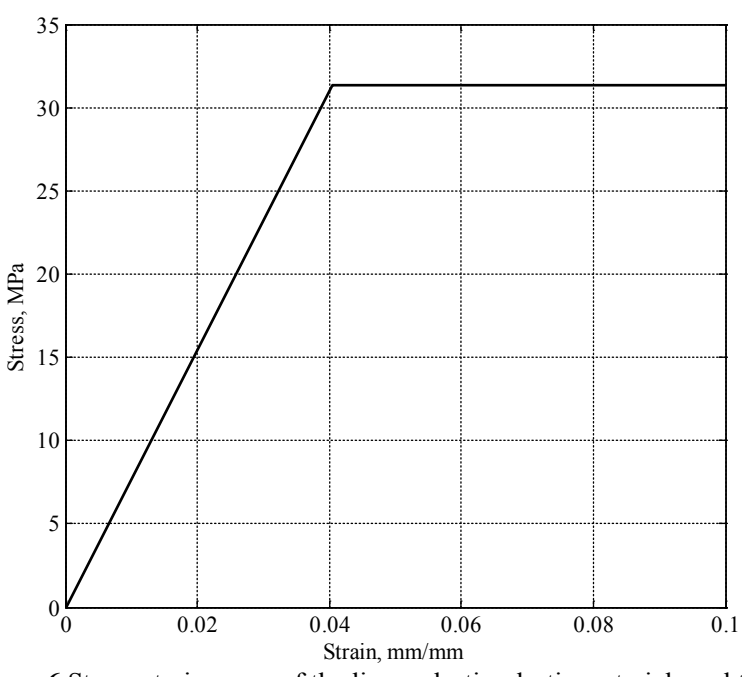

Figure 6 Stress-strain curve of the linear elastic-plastic material used to simulate the HWFSC in LaModel

\subsubsection{Modeling results}

1) Yielding of the fender pillar

Element strain can be used to analyze the post-peak coal behavior in LaModel [14]. Thus, the fender pillar yielding process in the three segments was studied by recording the strain of the elements in each simulation step.

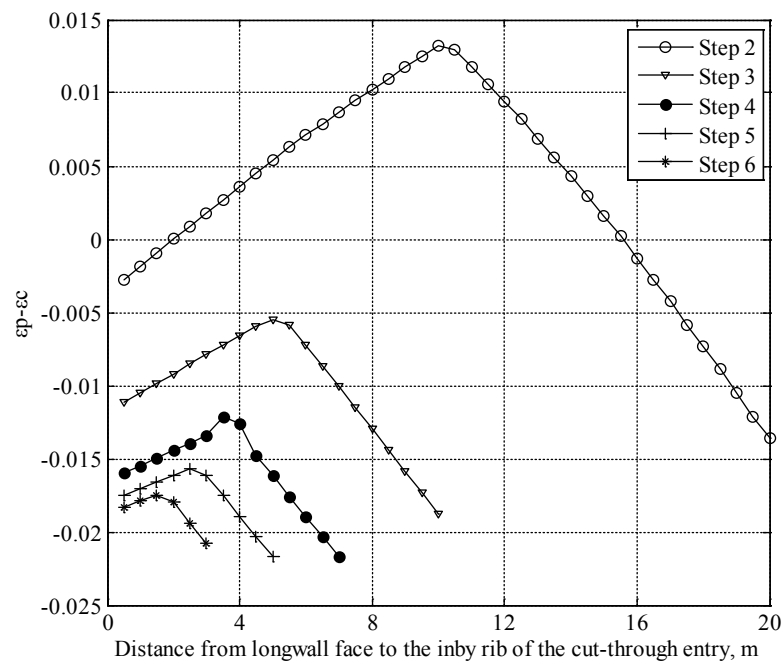

Figure 7 Yield process of the fender pillar in segment 1

Figs. 7 and 8 depict this yielding process during longwall retreat mining. The peak strain $\varepsilon p$ corresponds to the point beyond which the element enters the post-failure region, whereas $\varepsilon c$ is the current strain of the element. Therefore, the negative area of the vertical axis represents the yield state of the elements in both figures, whereas the positive portion suggests that the elements remain elastic. Specifically, Fig. 7 shows the process of fender pillar yielding in segment 1: (1) the entire fender pillar fails if its width is equal to or is less than $10 \mathrm{~m}$; and (2) the yield zone is distributed across both sides of the fender pillar and may account for $1 / 3$ of the width of the entire pillar when it is $20 \mathrm{~m}$ wide. However, this pillar does not fail completely if the cut-through entry is backfilled with HWFSC materials even if the long wall face cuts into the cut-through entry at $7 \mathrm{~m}$, as indicated in Fig. 8.

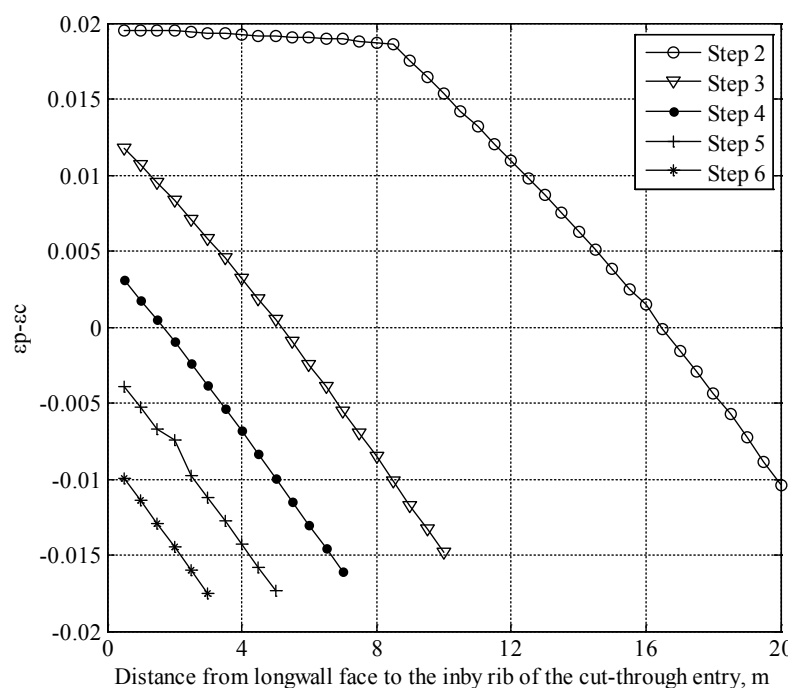

Figure 8 Yield process of the fender pillar in segment 2

The yield zone of the fender pillar in segment 3 at different simulation steps was not illustrated because it is similar to that in segment 1 .

2) Safety of the roof support design

The proposed roof support designs can be evaluated based on the stresses or loads of the supporting materials and the roof-to-floor convergences (Tab. 5) in the cutthrough entry during retreat simulation. As per Tab. 5, the wood cribs in both segments 1 and 3 yield completely when the fender pillar is $10 \mathrm{~m}$ wide or less (step 3) because the peak stress of the wood cribs is $0,532 \mathrm{MPa}$ (Fig. 5). Moreover, the final loads on the wood cribs in segment 1 weigh 136,08 metric tons, whereas those in segment 3 are slightly heavier at 137,7 metric tons. Nonetheless, the maximum stress on the HWFSC materials is $12,8 \mathrm{MPa}$, which is only $40 \%$ of its peak strength (Fig. 6). Thus, the backfilled material does not fail when the long wall face reaches the cut-through entry.

Table 5 Average vertical stresses and loads on the wood cribs and on the HWFSC materials in LaModel.

\begin{tabular}{|c|c|c|c|c|c|c|}
\hline \multirow[b]{2}{*}{ Steps } & \multicolumn{2}{|c|}{ Wood cribs in segment 1} & \multicolumn{2}{|c|}{ HWFSC materials in segment 2} & \multicolumn{2}{|c|}{ Wood cribs in segment 3} \\
\hline & $\begin{array}{c}\text { Average stress / } \\
\mathrm{MPa}\end{array}$ & $\begin{array}{c}\text { Average load / } \\
\text { tons }\end{array}$ & $\begin{array}{c}\text { Average stress / } \\
\mathrm{MPa}\end{array}$ & $\begin{array}{l}\text { Average load / } \\
\text { tons }\end{array}$ & $\begin{array}{c}\text { Average stress / } \\
\mathrm{MPa}\end{array}$ & $\begin{array}{l}\text { Average load / } \\
\text { tons }\end{array}$ \\
\hline Step 1 & 0 & 0 & 0 & - & 0 & 0 \\
\hline Step 2 & 0,425 & 34,425 & 3,25 & - & 0,425 & 34,425 \\
\hline Step 3 & 1,07 & 86,67 & 5,7 & - & 1,1 & 89,1 \\
\hline Step 4 & 1,44 & 116,64 & 8,15 & - & 1,47 & 119,07 \\
\hline Step 5 & 1,58 & 127,98 & 10,5 & - & 1,6 & 129,6 \\
\hline Step 6 & 1,66 & 134,46 & 12 & - & 1,68 & 136,08 \\
\hline Step 7 & 1,68 & 136,08 & 12,8 & - & 1,7 & 137,7 \\
\hline
\end{tabular}


Tab. 6 shows the roof-to-floor convergences in three segments of the cut-through entry with respect to the seven simulation steps. The final convergences in segments 1 and 3 account for half of the entry height and differ only slightly in all situations, whereas that in the segment 2 is only $58 \mathrm{~mm}$.

Table 6 Average roof-to-floor convergences in the cut-through entry in LaModel

\begin{tabular}{|c|c|c|c|}
\hline \multirow{2}{*}{ Steps } & \multicolumn{3}{|c|}{ Roof-to-floor convergences / mm } \\
\cline { 2 - 4 } & Segment 1 & Segment 2 & Segment 3 \\
\hline Step 1 & 13 & 13 & 13 \\
\hline Step 2 & 87 & 15 & 87 \\
\hline Step 3 & 874 & 26 & 917 \\
\hline Step 4 & 1401 & 37 & 1443 \\
\hline Step 5 & 1600 & 47 & 1628 \\
\hline Step 6 & 1714 & 54 & 1742 \\
\hline Step 7 & 1742 & 58 & 1770 \\
\hline
\end{tabular}

In summary, the fender pillar yielding process and the roof-to-floor convergences predicted with the modeling results indicate that the use of HWFSC materials to backfill the cut-through entry completely is safe because the longwall face cuts into this entry.

\subsection{Field monitoring results}

To evaluate the influence of front abutment pressure on the performance of the supports on the cut-through entry, this study recorded various issues as the longwall face approached the cut-through entry, such as fender pillar spalling, roof-to-floor convergences, and shield leg pressures. The final field monitoring results are presented in Tab. 7. Numerous roof cracks and severe fender pillar spalling were observed in both segments 1 and 3 when the face reached the entry, whereas segment 2 was normal. Significant roof-to-floor convergences were observed in segments 1 and 3, but segment 2 displayed only $100 \div$ $200 \mathrm{~mm}$ roof-to-floor convergence. In fact, the numerical modeling results indicated that the final roof-to-floor convergence in segment 2 was only $58 \mathrm{~mm}$ (Tab. 6). The discrepancy between the modeled results and the field observation may be attributed to the poor initial contact between the roof and the top surface of the grouting materials in the field.

The shields shouldered the least load when the face moved toward the entry. Thus, fewer shield components were damaged in segment 2 than in segments 1 and 3.

Table 7 Influence of front abutment pressure on the stability of the cut-through entry

\begin{tabular}{|c|c|c|c|}
\hline \multirow{2}{*}{ Roof condition } & Segment 1 & Segment 2 & Few cracks \\
\cline { 2 - 4 } & Numerous cracks & $100 \div 200$ & Normal \\
\hline Fender pillar spalling & Serious & 25 & $1600 \div 1700$ \\
\hline $\begin{array}{c}\text { Final roof-to-floor } \\
\text { convergences, mm } \\
\text { the legs of the shields, } \\
\mathrm{MPa}\end{array}$ & 36,8 & 38,2 \\
\hline $\begin{array}{c}\text { Yveld state of the legs } \\
\text { of the shield }\end{array}$ & $\begin{array}{c}70 \% \text { of the changes in the leg } \\
\text { pressure during a shield support } \\
\text { cycle was attributed to yielding. }\end{array}$ & $\begin{array}{c}\text { pressure changes during a shield } \\
\text { support cycle was ascribed to } \\
\text { yielding. }\end{array}$ & $\begin{array}{c}\text { pres of the changes in the leg } \\
\text { pressure during a shield support } \\
\text { cycle was attributed to yielding. }\end{array}$ \\
\hline $\begin{array}{c}\text { Shields condition } \\
\text { Many components were damaged. }\end{array}$ & $\begin{array}{c}\text { Only a few components were } \\
\text { damaged. }\end{array}$ & Many components were damaged. \\
\hline
\end{tabular}

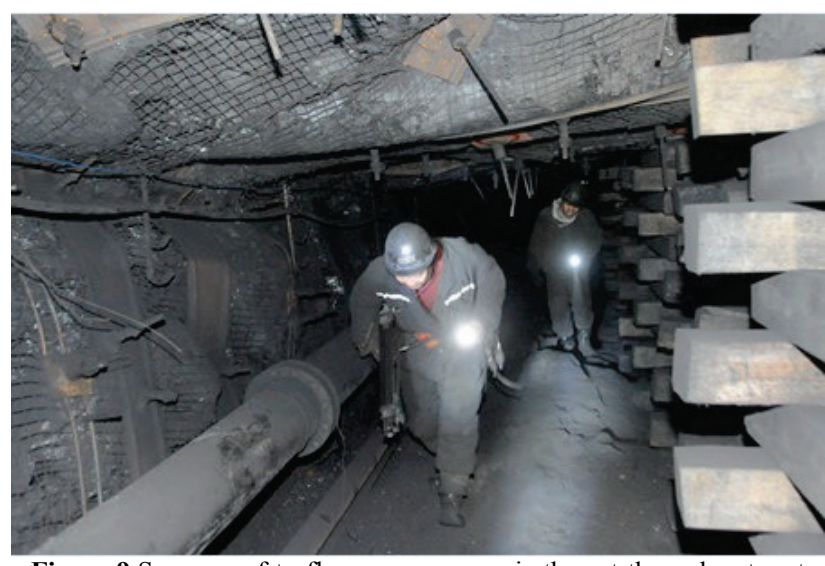

Figure 9 Severe roof-to-floor convergence in the cut-through entry at which conventional wood cribs were installed

Fig. 9 presents the severe deformation of the cutthrough entry during the approach of the longwall face. Fig. 10 displays the cuttability of the HWFSC material with the longwall shearer.

The use of HWFSC materials in backfilling was analyzed economically, as provided in Tab. 8. In terms of volume, the backfilled opening accounts for $1 / 3$ of the total cut-through entry. The total weight of the HWFSC consumed was 380 metric tons, and the total cost of backfilling was $\$ 61180$.

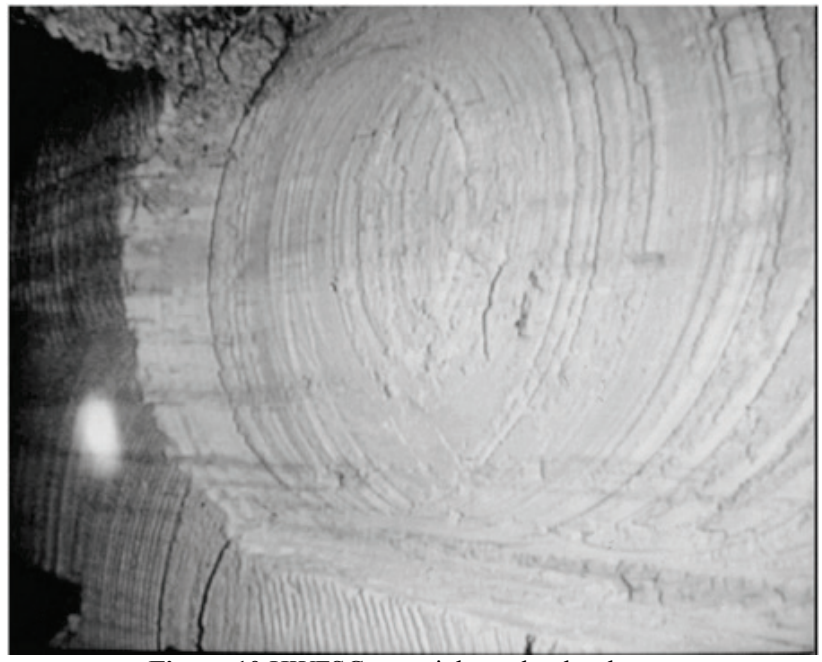

Figure 10 HWFSC materials cut by the shearer 
Table 8 Economic analysis of the use of HWFSC materials in backfilling

\begin{tabular}{|c|c|c|c|}
\hline $\begin{array}{c}\text { Backfilled } \\
\text { opening volume } \\
/ \mathrm{m}^{3}\end{array}$ & $\begin{array}{c}\text { Total consumed } \\
\text { HWFSC / tons }\end{array}$ & $\begin{array}{c}\text { Unit price } \\
\text { of HWFSC } \\
\$ / \text { ton }^{*}\end{array}$ & $\begin{array}{c}\text { Total cost of } \\
\text { HWFSC / \$ }\end{array}$ \\
\hline 1260 & 380 & 161 & 61180 \\
\hline
\end{tabular}

\section{Conclusions}

In longwall mining, a cut-through entry may be necessary because of ventilation regulations, safety concerns, and other mine-specific conditions. Nonetheless, the entry roof and the fender pillar must remain stable during longwall retreat mining. Although several support techniques can be used to control and to limit the opening of the entry, as well as the deformation of the fender pillar, these methods are either too expensive for application or are under rigid site constraints as per this paper.

To enhance the safety of underground mining without significantly affecting ground control issues, HWFSC was introduced in this study. Its performance depends on the selected W/S ratio. A serial of laboratory UCS tests were conducted on the HWFSC specimens at W/S ratios that range from 1,0 to 3,0 , and the results show that: (1) HWFSC gradually shifts from brittle to ductile as the W/S ratio increases and (2) the peak strength of the HWFSC specimens decreases significantly with the increase in W/S ratio, although residual strength increases considerably.

The field application was validated by backfilling cut-through entries with HWFSC in a case study. Three roof support strategies were presented: the strategy involving conventional wood cribs arranged in one row, the strategy involving conventional wood cribs arranged in two rows, and complete backfilling with HWFSC. The results of the numerical simulation of the fender pillar yielding process and the safety of the roof supports suggest that: (1) the critical pillar width was $10 \mathrm{~m}$ when wood cribs were used as supplementary roof supports, regardless of whether one or two rows was installed. Furthermore, the final roof-to-floor convergences account for half of the entry height. (2) The fender pillar does not fail completely even when the longwall face cuts into the cut-through entry at $7 \mathrm{~m}$ after complete backfilling. Moreover, its final roof-to-floor convergence is only 58 $\mathrm{mm}$.

Finally, the economic analysis results indicated that the total cost of the use of HWFSC materials in backfilling was only $\$ 61180$, which was a major advantage.

\section{Acknowledgements}

This research was sponsored by the National Natural Science Foundation of China through Contract No. 51174195. The authors would also like to express their sincere appreciation and gratitude to Dr. Heasley for his help on the LaModel simulation and for his critique, which improved this paper.

\section{References}

[1] Tadolini, S. C.; Barczak, T. M. Design Parameters of Roof Support Systems for Predriven Longwall Recovery Rooms. // Transactions-society for mining metallurgy and exploration incorporated. 318, (2006), pp. 87.

[2] Peng, S. S. Coal Mine Ground Control. 3rd ed. Morgantown, West Virginia, 2008.

[3] Zhang, P.; Heasley, K. A. Initial Results from Implementing a Laminated Overburden Model into ARMPS. // Proceedings of the $32^{\text {nd }}$ International Conference on Ground Control in Mining / Morgantown, West Virginia, 2013, pp. 239-247.

[4] Peng, S. S. Cutting Through Open Entries Requires Proper Support. // Coal Age. 105, 6(2000), pp. 37-40.

[5] Wichlacz, D.; Britten, T.; Beamish, B. Development of a Pre-Driven Recovery Evaluation Program for Longwall Operations. // Proceedings of the 2009 Coal Operators' Conference / Wollongong, 2009, pp. 23-36.

[6] Oyler, D. C.; Mark, C.; Dolinar, D. R.; Frith, R. C. A Study of the Ground Control Effects of Mining Longwall Faces into Open or Backfilled Entries. // Geotechnical and Geological Engineering. 19, 2(2001), pp. 137-168.

[7] Seymour, J. B.; Tesarik, D. R.; Larson, M. K.; Shoemaker, J. Stability of Backfilled Cross-Panel Entries during Longwall Mining. // Proceedings of the 17th International Conference on Ground Control in Mining / Morgantown, West Virginia, 1998, pp. 11-20.

[8] Chen, H.; Peng, S.S. Mechanisms of Roof Failure in Longw-all Entry System under High Horizontal Stress Conditions. // Proceedings of the SME Annual Meeting / Denver, Colorado, 1997, pp.10-18. URL: http://www.onemine.org/search/summary.cfm/MechanismOf-Roof-Failure-In-Longwall-Entry-System-Under-HighHorizontal-Stress-

Conditions? $\mathrm{d}=123456789012345678901234567890123456$ $7890123456789012345678901234177777 \&$ fullText=cutter \&start $=100$.

[9] Barczak, T.; Tadolini, S.; Zhang, Y. Evaluation of Support and Ground Response as Longwall Face Advances into and Widens Pre-Driven Recovery Room. // Proceedings of the 26th International Conference on Ground Control in Mining / Morgantown, West Virginia, 2007, pp. 160-172.

[10] Bauer, E. R.; Listak, J.; Berdine, M. Assessment of Experimental Longwall Recovery Rooms for Increasing Productivity and Expediting Equipment Removal Operations. US Department of the Interior, Bureau of Mines; 1989.

[11] Gao, F.; Stead, D.; Kang, H. Numerical Simulation of Squeezing Failure in a Coal Mine Roadway due to MiningInduced Stresses. // Rock Mechanics and Rock Engineering, 2014. doi: 10.1007/s00603-014-0653-2.

[12] Barczak, T; Tadolini, S. Pumpable Roof Supports: An Evolution in Longwall Roof Support Technology. // Transactions-society for mining metallurgy and exploration incorporated. 324, (2005), pp. 19-31.

[13] Heasley, K. A. Numerical Modeling of Coal Mines with a Laminated Displacement-Discontinuity Code. Dissertation, Colorado School of Mines, 1998.

[14] Heasley, K. A. Back Analysis of the Crandall Canyon Mine Using the lamodel Program. // West Virginia University, Research report. The Web version (2008) pp. 3-10. URL: http://web.cemr.wvu.edu/ kheasley/LaModelDownloads/D ocuments/CrandallCanyonReport/CrandallCanyonBackAna lysis.pdf.

[15] Wang, Q. Integrated Stability Mapping System for Mines. Dissertation, West Virginia University, 2005.

[16] Heasley, K. A.; Agioustantis, Z. G. LaModel: A boundaryelement program for coal mine design. // Proceedings of the New Technology for Ground Control in Multiple-Seam 
Mining / Pittsburgh, Pennsylvania. US Department of Health and Human Services, Public Health Service, Centers for Disease Control and Prevention, National Institute for Occupational Safety and Health, DHHS (NIOSH) Publication, 2007, pp. 29-33.

[17] Karabin, G. J.; Evanto, M. Experience with the BoundaryElement Method of Numerical Modeling to Resolve Complex Ground Control Problems. // Proceedings of the 18th International Conference on Ground Control in Mining / Morgantown, West Virginia, 1994, pp. 89-113.

[18] Salamon, M. D. G. Mechanism of caving in longwall coal mining. Rock Mechanics Contributions and Challenges. // Proceedings of the $31^{\text {st }}$ US Symposium / Golden, Colorado, 1990, pp. 161-168.

[19] Mucho, T.; Barczak, T.; Dolinar, D. Design Methodology for Standing Secondary Roof Supports in Longwall Tailgate. // Proceedings of the $18^{\text {th }}$ International Conference on Ground Control in Mining / Morgantown, West Virginia, 1999, pp. 136-148.

[20] Hoek, E; Brown, E. T. Practical Estimates of Rock Mass Strength. // International Journal of Rock Mechanics and Mining Sciences, 34, 8(1997), pp.1165-1185.

[21] Tan, T. Effects of Triaxial Stress on Concrete. // Proceedings of the $30^{\text {th }}$ Conference on Our World in Concrete and Structures / Singapore, Nanyang Technological University. 2005. URL: http://cipremier.com/100030007.

\section{Authors' addresses}

\section{Jingyi Cheng, doctoral candidate}

Institution:

(1) Department of Mining Engineering, West Virginia University, Morgantown, WV, 26506, United States

(2) School of Mines, Key Laboratory of Deep Coal Resource Mining, Ministry of Education of China, China University of Mining and Technology, Xuzhou, Jiangsu, 221116, China Postal address:

Statler College of Engineering and Mineral Resources, 169 Mineral Resources Building, P.O. Box 6070, Morgantown, WV 265066070, United States

Tel.: +1 3047770662

E-mail: cjycumt@hotmail.com

Wenfeng Li, doctoral candidate, corresponding author

Institution:

(1) Department of Mining Engineering, West Virginia University, Morgantown, WV, 26506, United States

(2) School of Mines, Key Laboratory of Deep Coal Resource Mining, Ministry of Education of China, China University of Mining and Technology, Xuzhou, Jiangsu, 221116, China Postal address:

Statler College of Engineering and Mineral Resources, 169 Mineral Resources Building, P.O. Box 6070, Morgantown, WV 265066070, United States

Tel.: +1 3047770581

E-mail: 1wfcumt@yahoo.com

\section{Peng Zhang, PhD}

Institution:

Carlson Software, Watertown, MA, 02460, United States

Postal address:

480 Pleasant St, Suite C100, Watertown, MA 02472, United States

Tel.: +1 6173932300 , ext. 415

E-mail: pzhang@carlsonsw.com 